\title{
FÖLDRAJZTANÁR SZAKOS HALLGATÓK MAGYAR-SZERB ORSZÁGHATÁRSÁV-KÉPZETE - ELŐFELMÉRÉS SZEGEDEN
}

\section{Balázs Brigitta}

\begin{abstract}
Absztrakt: A szegedi földrajztanár szakos egyetemista hallgatók körében készült felmérés a mentális térkép kutatási módszertana alapján történt. A vizsgálat célja betekintést nyerni a földrajz szakos hallgatók Magyarország dél-keleti határvidékéről alkotott mentális képéről, valamint a hiányosságok feltárásával egy a későbbiekben reprezentatív mintán történỏ vizsgálat előkészítése, módszertani kidolgozása.
\end{abstract}

\begin{abstract}
This preliminary/pilot study aims at determining the geographical topographical knowledge of Hungarian geography teacher university students in Szeged about Hungary's southeastern border, through mental maps. In addition our survey aimed to the preparation and evaluation of a measuring device that is capable of bringing to the surface this mental boundary images. Moreover this researching investigation of the shortcoming is help us to development of methodology for a later examination.
\end{abstract}

Kulcsszavak: kognitív térkép, mentális térkép, országhatár, téri reprezentáció. szegedi földrajz tanári szakos diákok

Keywords: cognitive map, mental map, boundary, spatial perception, geography teacher students in Szeged

\section{A szubjektív térérzékelés ismertszerzési szerepe (kognitív és mentális térképeink)}

Amennyire lényeges megértenünk az ember fizikai környezetét ugyanolyan fontos megpróbálni értelmezni az emberek szubjektív környezetét is, amely formálja az egész világgal és annak részeivel (kontinensek, országok, települések) kapcsolatos képeinket. Így az egyének és kultúrák környezeti érzékelésének vizsgálata egy olyan kutatási területté válik, ahol a valóságos fizikai világ és az egyénnek e világról alkotott érzékelése közötti különbséget a földrajz tudományágaként a behaviorista és a kognitív geográfia vizsgálja (Sudas-Gokten, 2012). Ezen megközelítések szempontjából a tér az objektív valóság egyfajta szubjektív észlelése, amely részben segíti az egyén térbeli tájékozódását is, amikor a valóságot fejben leképezve kognitív térképek jönnek létre (Cséfalvay, 1990).

Ezen szubjektív térérzékelés során a tér elemeinek észlelését az egyén információtároló képessége, a rövid- és hosszú távú memória müködési sajátosságai, a tanulás folyamata, a személyiség, az attitüdök és a környezethez füzödő viszony egyaránt befolyásolják (Poreisz, 2013). Vagyis ezen képességek az egyén fejlödése és a tanulás függvényében folyamatosan formálódhatnak (Uszkai, 2015a). Ennek során az ember az öt körülvevő fizikai környezetről tudati képet alakít ki, megtörténik a külső világ belső leképezése, vagyis saját gondolati terünk, térrendszerünk létrehozása (Cséfalvay, 1990).

Az így létrejött kognitív (Tolman, 1948; Downs-Stea, 1977, 2005) és mentális (Lynch, 1960) jelzővel illetett térképek fogalmát szakirodalmi tudományos 
értelmezések alapján (Cséfalvay, 1990; Kiss, 2005; Garda, 2009; Rácz, 2012) a következöképpen különítjük el: a kognitív térképezés során egy komplex pszichológiai folyamat eredményeként kialakul a valóságos térnek egy sajátos értelmezése, a kognitív térkép. A mentális térképezés lényege ennek az egyénekben rejlö kognitív térképeknek a feltárása, így az az egyén kognitív térképének adott eszközökkel megjelenített részét képezi (Kiss, 2005). Az előzőekből következik, hogy környezetünk térbeli viszonyainak megértése ezen kognitív térképek alapján történik, s ennek megfelelö kialakítása előfeltétele az egyén navigációs képességének a fejlödésében (Herendiné Kónya, 2007). Lényeges megjegyezni, hogy ez a térkép mindenkinél egyéni lehet, ugyanakkor az oktatás során arra törekednek, hogy ez a „térkép” minél objektívebben képezze le a fizikai valóságot (Farsang, 2011). Tehát a kognitív térképek a legfőbb eszközei annak, hogy azonosítsuk a térrel kapcsolatos érzékeléseket, és különbséget tegyünk fizikai és szubjektív környezet között (Milgram, 1972). Ennélfogva a kutatási kérdések, a térrel kapcsolatos ismeret megválaszolására Didelon et al. (2011) nyomán a kérdőíven alapuló, klasszikus mentális térképezés kulcsinger felidézés módszerét (irányított felidézés) használtam, mely alkalmas a világ különböző tulajdonságaival kapcsolatos ismeretek, személyes készségek értékelésére (Saarinen-Maccabe 1995; Wiegand, 1998).

\section{Magyarországi mentális térkép kutatások alap,- közép- és felsőfokú tanulmányokat folytatók körében a szakirodalmi tanulmányok tükrében}

$\mathrm{Az}$ országképek vizsgálata a mentális térképek egyik fontos kutatási kategóriája. Ezen belül a kutatások három csoportra oszthatók: (1) egy kontinens pozitív és negatív területeinek vizsgálata; (2) szomszédos országok vizsgálata; (3) egy adott országról kialakult kép elemzése (Garda, 2009). Jómagam ide sorolnám be külön kategóriát létrehozva a (4) mentális határ vizsgálatokat is. A továbbiakban jelen írásban ez első kettő és negyedik kategóriába tartozó kutatásból említenék meg néhányat.

\subsection{Egy adott terület pozitív és negatív megitélésének vizsgálatába tartozó kutatások}

Kiss - Bajmócy szerzőpáros (1996) egyetemi hallgatók (208fö) mentális térképeit vizsgálták Magyarországra vonatkozóan. Többek között arra voltak kíváncsiak, hogy milyen térbeli képzödményeket tartalmaznak az egyetemisták fejében élő térképek, $s$ térképzeteik létrehozásában milyen tényezők játszanak szerepet. Kutatásuk egyik fóbb következtetése volt, hogy az egyetemisták tudatából is kikapcsolódnak a hátrányos helyzetü területek, $s$ magatartásuk térbeli viszonyítási pontjai inkább a fejlett, vagy perspektivikus vidékekhez kötődnek (Kiss-Bajmócy, 1996).

Bajmócy - Csíkos szerzőpáros 1995-1996-ban végzett felmérésének célja volt az egyetemi hallgatók véleményének megismerése az európai országok népszerüségére vonatkozóan. Eredményeiket összevetve Csapó Benő és Czachesz 
Erzsébet (1995) általános és középiskolás fiatalok körében végzett korábbi vizsgálatával arra a megállapításra jutottak, hogy az egyetemisták véleménye nem sokban különbözött a középiskolásokétól. Tehát az egyetemisták európai országokkal kapcsolatos attitüdjeinek kialakulására meghatározó szereppel bír az alap-és középfokú oktatásban eltöltött időszak (Bajmócy-Csíkos, 1997).

Makádi Mariann (2012) a 6-10. osztályosok tanulók Európa-képzetét vizsgálata a fejünkben élő térképek fejlesztésével kapcsolatosan. Következtetései között szerepel, hogy a diákok térképzete nem tartalmaz maradandó téri ismereteket, tehát az Európához és annak országaihoz kapcsolt tartalmi képzetek alapján hiányosságai vannak a földrajztanításnak. Viszont a szerző cikkében javaslatokat tesz a térrel kapcsolatos tudás fejlesztési lehetőségeire vonatkozóan (Makádi, 2012). S láthatjuk, hogy a mentális térképezés eszköze a földrajzoktatás fejlesztésére is alkalmazható kutatási módszer.

Kincses Áron és Jakobi Ákos 2012-ben megjelent cikkében beszámolt a 20092010 között az Eurobroadmap projekt keretében vizsgált 18 ország közül a magyarországi egyetemi hallgatókra vonatkozó (244fő) eredményekről. A kutatás keretében az egyetemisták véleményét vizsgálták a világról és Európáról, hogy milyen szubjektív képpel vannak a diákok a világ egyes területeiről. A főbb következtetések közül a szerzők kiemelték, hogy a szomszédos országokat sokkal kevésbé szeretik a magyar egyetemisták, mint a távolabb esőket, amelyekröl azonban kevesebb információval rendelkeznek (Kincses-Jakobi, 2012).

Egy nemzetközi publikációban Ilkay Sudas és Cemil Gokten (2012) kutatásának célja volt a mentális térképeken keresztül a török geográfus hallgatók Európával kapcsolatos földrajzi ismereteinek meghatározása. Eredményeikkel hozzájárulni kívántak az Európa-kép megértéséhez, a török diákok kompetenciáinak a fejlesztéséhez. Úgy vélik az Európa topográfiai alapismeretek az első lépése annak, hogy elérjék az európai kompetenciák fejlesztését, amit elsősorban a fölrajz tanárok tudnak kifejleszteni. Ezért is fontos megtudnunk milyen Európa-kép él a földrajz szakra járó hallgatók fejében, mint a jövő tanáraiban. A részben hiányos ismeretek létét igazolják, hogy a hallgatók térképein meglévő térképzetekként szerepel Csehszlovákia és Jugoszlávia megemlítése (Sudas-Gokten, 2012).

\subsection{A szomszédos országok vizsgálata}

Hazánk Európai Unióhoz való csatlakozása felvetette azt a kérdést, vajon milyen kognitív képpel rendelkeznek az emberek, amit több úttörő tudományos munka is vizsgált hazánkban (Székely, 2002; Székely-Kotosz, 2005). Jelen tanulmányhoz szorosan kapcsolódva például a 14-16 éves magyarországi tanulók szomszédos országainkról? - kérdésre adott válaszok alapján tárták fel a mentális térképeit a hazai tizenéveseknek (Lakotár, 2004). A tanulók Magyarország kontúrtérképét kapták meg, ahol feladatuk hazánk szomszédos országainak berajzolása és megnevezése. A vizsgálat alapján bebizonyosodott, hogy a kognitív térképek kialakításában központi szerepe van az egyén személyes tapasztalatainak, a környezetböl szerzett információknak, valamint a médiának (Lakotár, 2004). 
Kutatási munkám szempontjából kiemelendő Lakotár Katalin egy másik (2012) vizsgálata, aki az előző kérdést fordított szempontból is megvizsgálta, s felmérte, hogy vajon milyen Magyarország-kép él a határinkon túl, azok közelében élö magyar diákokban. A Magyarország hívószóra kirajzolódott mentális Magyarország térképeken a szerb tanulók válaszai a szerb és nyugat szlovákiai határszakaszon a valóságoshoz közelítettek; addig a romániai tanulók esetében a közös határmente nem volt része a mentális térképeknek. Ugyanakkor a diákok közvetlenül az országhatárokkal kapcsolatos térérzékelésének felmérésével Magyarország és a környező hét ország kapcsán - tudomásunk szerint - eddig még nem foglalkoztak átfogóan, igaz, felmeruilt a vizsgálatokban a határközeliség módosító szerepének a mentális képekben való megjelenése (Kiss-Bajmócy, 1996; Lakotár, 2012).

\subsection{A mentális határ vizsgálata}

$\mathrm{Az}$ országhatárok megnyitása az Európai Közösség országai között hatalmas mennyiségü gazdaság földrajzi szakirodalom megjelenését eredményezte, azonban meglepően kevés írás született az állampolgárok megélt nézöpontjairól (Houtum, 1999). Uszkai Andrea azonban megfogalmazta azt, hogy miért hasznos ezen témakör kutatásával foglalkozni, miszerint a „mentális határok egyfajta „szellemi korlátként" léteznek a különbözö államok lakóinak gondolatvilágában, és ezáltal jelentösen befolyásolják az emberek térfelfogását, közösségi tudatukat és a határon túl élókröl alkotott képet, elöitéletet” (Uszkai, 2015b: 157). A „mentális határ” fogalom tehát nem más, mint az emberekben kognitívan leképeződő „határkép”, azaz a határ másik oldalának megélése, megítélése, szubjektív képzete (Uszkai, 2015b).

Hardi Tamás (1999) a tudati tér közeledését és távolodását vizsgálta az osztrákmagyar határszakaszon abból a feltételezésböl kiindulva, hogy a bizonyos akadályok általi korlátozó tényezők (folyó, országhatár) következtében a túloldali települést sokkal távolabbinak érezzük, mint azt, ami a mi oldalunkon van. Ugyanakkor Hardi véleménye szerint ez a tudati, mentális távolság módosul az határ átjárhatóságával. Kérdőíves és fókusz-csoportos kutatásában 4-4 osztrákmagyar település lakosságát vizsgálta térképhasználat bevonásával. Eredményeiböl kiderül, hogy az akkor újonnan létrejött kis határátkelőhelyek adhatják az alapját annak, hogy a régen összetartozó területek társadalmi szinten újra összekapcsolódhassanak.

Sik Endre és Surányi Ráchel (2015) által szerkesztett Határhatások könyv vizsgálatai a magyar-ukrán, magyar-szlovák hármas-határszakaszra vonatkoznak, a határon átnyúló kapcsolatok, identitás témakörökben. Véleményük szerint a mind interdiszciplinárissá váló határkutatás önálló tudományterületté fejlődött, ahol sokasodnak a határ különleges csoportjaira, hatásaira fókuszáló kutatások: mentális térképek, a határ közelségének a lakosság regionális, etnikai és uniós identitására gyakorolt hatása (Sik-Surányi, 2015). Ezen könyv kutatásaiból emelnék most ki kettőt: Sik Dorka és Szécsi Judit (2015) kvalitatív vizsgálatának célja a régióban élö magyarországi és határon túli fiatalok határról alkotott véleményének a 
feltérképezése volt az iskolaiazgatókkal folytatott félig strukturált interjúk és a diákokkal történt fókuszcsoportos interjúk mentén. Vizsgálatuk célja volt felmérni, hogy milyen lehetőségeket és akadályokat jelent a diákok életében a hármashatár, valamint $\mathrm{mi}$ az iskolarendszer szerepe a fiatalok migrációs terveinek és jövőképének alakulásában. A kutatás a Beregszász, Királyhelmec és Sátoraljaújhely négy középfokú oktatási intézményeiben valósult meg. Eredményeiket tekintve megállapították, hogy a határ, mint téma nem jelenik meg az iskolák profiljában, s a határ közelség ellenére sem tanulnak a gyerekek bővebben a két szomszédos országról. Tehát kutatásuk igazolja, hogy a határ zártsága-nyitottsága a fiatalok életében is meghatározó szerepet tölt be. A szerzők úgy vélik attól, hogy Magyarország és Szlovákia is az EU tagjai a fejekben mégis erős határvonal él a korábbi valós vagy vélt sérelmek és félelmek következtében (Sik-Szécsi, 2015).

Koltai Júlia és Ligeti Anna Sára (2015) a határon túli területek szubjektív közelségét vizsgálta kiindulva abból, hogy az egyén lokális identitásának az alapja a földrajzi közelség. Úgy vélik, hogy a határon élők lokális identitása összetett jelenség, ugyanis a földrajzi teret átszeli az országhatár. Részeredményeiket nézve a területi hovatartozás és a nemzetiségi hovatartozás figyelembe vételével elmondhatjuk, hogy a határ túloldala felé érzett szubjektív közelség nagyon eltérő mintázatot mutat a különbözö területek és nemzetiségi csoportok mentén (KoltaiLigeti, 2015).

Baranyi Béla (2004) a határ (magyar-román, magyar-ukrán) két oldalán élők mentális térképei közötti különbségeket empirikus módszerekkel (kérdőív, interjú) vizsgálta. Külön figyelemreméltó, hogy a kutatása a határ mindkét oldalára kiterjedt, s emellett nem a megszokott metodikát követve valósult meg, hanem a válaszadóknak térkép nélkül, tehát emlékezetből kellett megadniuk a településeket. Az eredmények közlésétől szükösségi keretek miatt most jelen tanulmány eltekint.

Hardi Tamás 2013-2015 között kérdöíves vizsgálat mentén mérte fel Magyarország valamennyi határszakaszán túl a szomszédos országok egyetemista hallgatóinak véleményét az országuk elhelyezkedéséről, belső struktúrájáról, partnerségi viszonyairól. Vizsgálatának kiinduló gondolati között szerepelt a következő. Térszemléletünket amellett, hogy formálja az a földrajzi hely, ahol élünk és a földrajzoktatás ismereti tárháza figyelembe kell vennünk, hogy szerzett objektív ismeretinket befolyásolják elöítéleteink, egyéni tapasztalatink, reflexeink is, mely hatással vannak más államokhoz füződő attitüdünkre. Az eredmények közlésétöl most jelen tanulmány eltekint (Hardi, 2015).

Tehát amint a fentiekböl is láthatjuk a szubjektív térérzékeléssel kapcsolatos magyarországi kutatások közül már több is fókuszált a diákok nemzeti, nemzetközi kognitív térképeinek tanulmányozására (Farsang-Jóri, 1999; Lakotár, 2009a, 2009b, 2011, 2012; Makádi, 2012, 2013; Uszkai, 2015a,b). Ugyanakkor tényleges határkép felmérés az integrálódó európai térben diákok körében tudomásom szerint eddig még nem történt, noha Magyarországon különösen magas az ún. államhatársürüsödési metszéspontok száma (Baranyi, 2014), és Magyarország ún. „határ menti ország" (Hajdú, 2000). Ahol is az államhatár, mint korlátozó tényező 
befolyásolhatja, akadályozhatja a határ menti, szomszédos környezet megismerését (Hardi, 1999; Baranyi, 2004).

Az elméleti kutatásokat összegezve megállapítható, hogy például a kisebb és nagyobb léptékü gazdasági-politikai határváltozások (Vida, 2013, 2016), a határokon átlépő térértelmezési elvárások aktuálissá teszik annak felmérését, hogy milyen az intézményes földrajzoktatás oldaláról már kész ismeretekkel rendelkező diákok közvetlen környezetükre vonatkozó mentális „térképe”.

\section{A szegedi kutatásban résztvevő földrajz tanár szakos egyetemisták mentális térképei}

Ahhoz, hogy a határ menti terület középiskolás diákjainak a térérzékeléssel, topográfia ismeretrendszerrel kapcsolatos ismereteit feltérképezzem elsőnek is egy kismintás (11 fö) pilot-felmérést végeztem 2015 őszén a szegedi földrajz tanár szakos hallgatók körében a mérőeszköz (feladatlap) elkészítésének, fejlesztésének a céljaként. Mivel kutatásom fö kérdései a térérzékelésre, ismeretrendszerre fókuszálnak, így jelen dolgozatban a következőket emelném ki: Milyen mentális térbeli képpel bírnak az egyetemisták a határmenti területekre vonatkozóan? Milyen Magyarországgal határos, nem magyar határterületekkel kapcsolatos képpel rendelkeznek? Honnan indul $\mathrm{ki}$ a térképi orientációjuk? Milyen földrajzi objektumokat jelölnek? Milyen térbeli eltérés van a tényleges földrajzi helyzet és a diákok válaszai között?

A kontinensek tényleges és viszonylagos fekvésének a felismerése, leírása az intézményes oktatás korai szakaszában, a 6 . évfolyam végéig teljesítendő követelmény (Makádi, 2012). A diákok az európai országokkal 7. évfolyamon az Európa országainak természet- és társadalom-földrajza témakör, majd 8. évfolyamon Közép-Európa tájainak és országainak természet- és társadalomföldrajz téma keretében ismerkednek meg, így a diákok ekkorra részleges ország-képekkel bírnak, melyek a közép-és felsőfokú (földrajz) tanulmányok folyamán tovább formálódhatnak. Ennélfogva feltételezhető, hogy a határ mentén tanuló földrajztanár képzésben résztvevő egyetemisták számára nem jelenthet gondot, nagy kihívást a határsáv természetföldrajzi és társadalom földrajzi objektumainak felidézése és bejelölése. Belátható ez annak tudatában is, hogy annak ellenére, hogy igaz az a tény, hogy a felismerés és az emlékezetböl történő önálló felidézés igen eltérő gondolkodási szintet jelöl viszont a földrajz képzésben a diákoktól ez joggal elvárható. A bejelöléshez viszont szükséges a feladatlapon található térképi részlet megfelelő értelmezése, az adott térképhez kapcsolódó helyes térfelfogás, hogy mekkora is a kivágott térképi részlet, milyen távolra kerüljenek az objektumok egymástól ahhoz, hogy a fejünkben lévő képzetek a lapra kerülésük után az objektív valósághoz közelítsenek. Jelen esetben eltekinthetünk az ábrázolási, rajzolási készségek fejlettségi szintjétől az objektumok ponttal való jelölésének következtében.

Célom volt feltérképezni, hogy honnan indul ki a diákok térképi, térbeli orientációja az objektumok bejelölésének kezdetekor, ehhez a feladatlapok kitöltésekor a következőket kértem: „Jelöld be és nevezd meg emlékezetböl az 
ismert földrajzi neveket a magyar-szerb határszakaszt jelölö alábbi térképvázlaton! Tegyél csillagot ahhoz a földrajzi névhez, melyet elsóként bejelöltél és megneveztél!" Látható, hogy a diákok közel felénél Szeged városa jelenti a kiindulási pontot, de figyelemreméltó, hogy vannak, akik természeti képződményekhez viszonyítanak (Tisza) vagy figyelmen kívül hagyják az utasításokban elhangzó kérést (1. ábra).

\section{1. ábra: A térképi orientáció kiindulási pontjai}

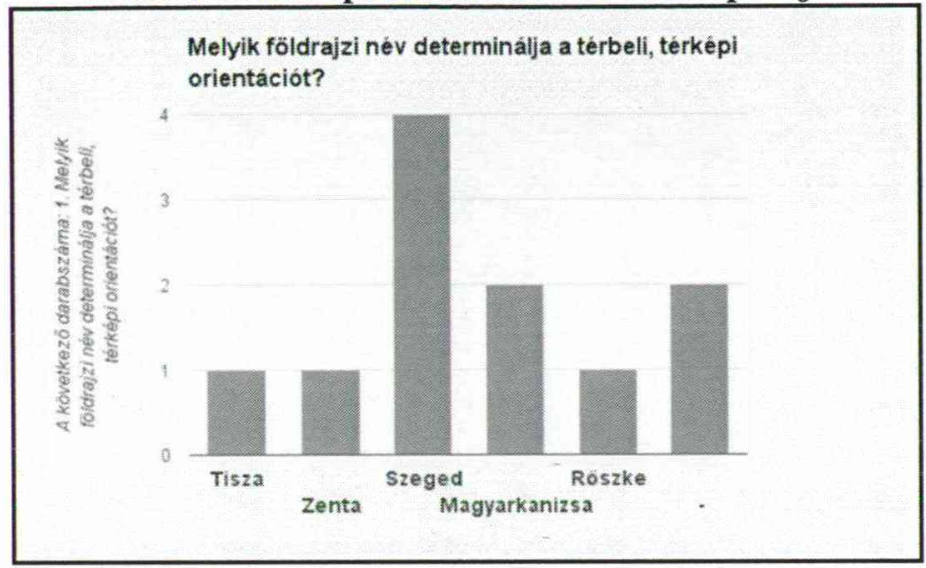

Forrás: A szerző felmérése alapján (2015)

A felmérés egyik fő kérdése az volt, hogy milyen mentális kép rajzolódik ki a délkeleti országhatárral kapcsolatosan a diákok képzeteiben. A 11 feladatlapon összesen 108 földrajzi elem jelölése történt meg egy feladatlap kivételével mind a magyar, mind a szerb határszakaszon történő bejelöléssel, ebböl 39 féle település $(53,85 \%$ magyar, $38,46 \%$ szerb, $5,13 \%$ román és $2,56 \%$ horvát), melyek több esetben is megjelentek a mentális térképeken. A legkevesebb bejelölést tartalmazó térkép három, a legtöbb bejelölést tartalmazó térképvázlatok 19 elemet foglaltak magukba (2. ábra), viszont az objektumok közül elenyésző számban jelentek meg természetföldrajzi nevek említései. 


\section{2. ábra: Az egyetemisták mentális térképeinek földrajzi névre vonatkozó} számszerủ adatai, ezen belül a természet földrajzi objektumok megoszlása

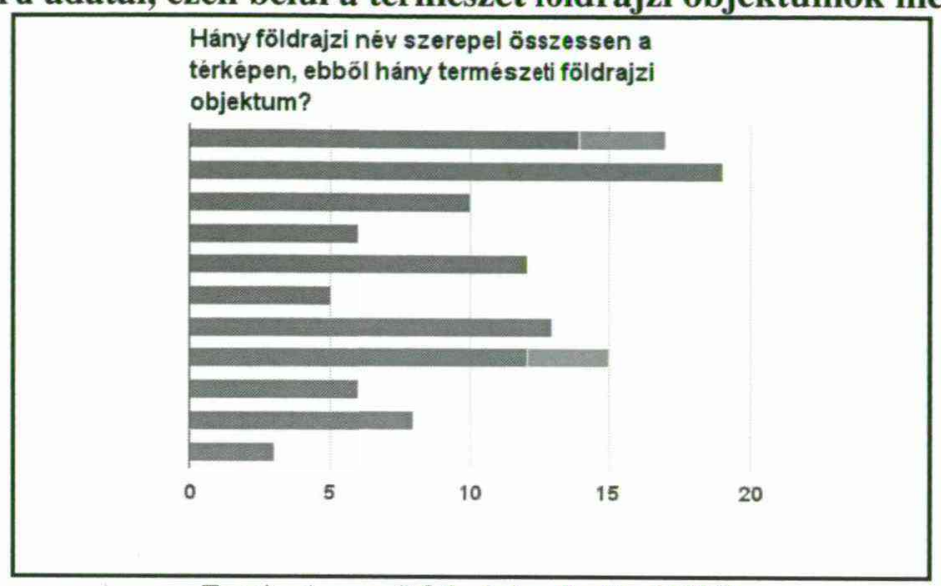

Forrás: A szerző felmérése alapján (2015)

A diákok által megemlített topgráfiai és egyéb földrajzi kifejezések összesített táblázatát az 1. táblázat szemléleti.

\section{1. táblázat: Az egyetemisták mentális térképein megjelenő földrajzi nevek}

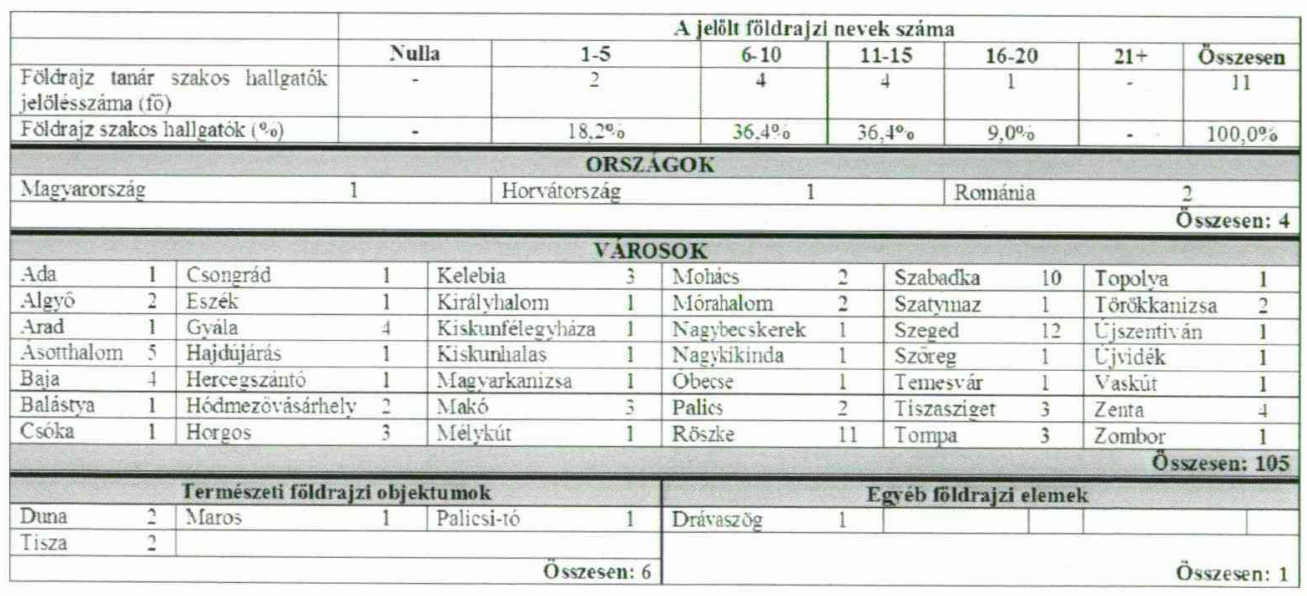

Forrás: A szerző felmérése alapján (2015)

Abban az esteben ha a térképi helyezt, mértarány értelmezés, valamint a térérzékelés szempontjából vizsgáljuk a mentális térképi bejöléséket, akkor azt tapasztalhatjuk, hogy két csoportra oszthatjuk a hallgatók mentális térképeit: (1) egyfelöl azok, ahol az ábrázolásokat tekintve történt a lapon lévő országhatárhoz és méretarányokhoz megfelelö viszonyítás (3. ábra), illetve (2) másfelöl, ahol ez csak némiként valósultak meg (4. ábra). Szerencsére ez utóbbiból találunk kevesebbet a térképek között, ahol a település objektumok eredeti helyzetükhöz képest szétszórva (szétszoró-típusú) jelennek meg. 


\section{3. ábra: Megfelelő téri viszonyítású mentális térkép}

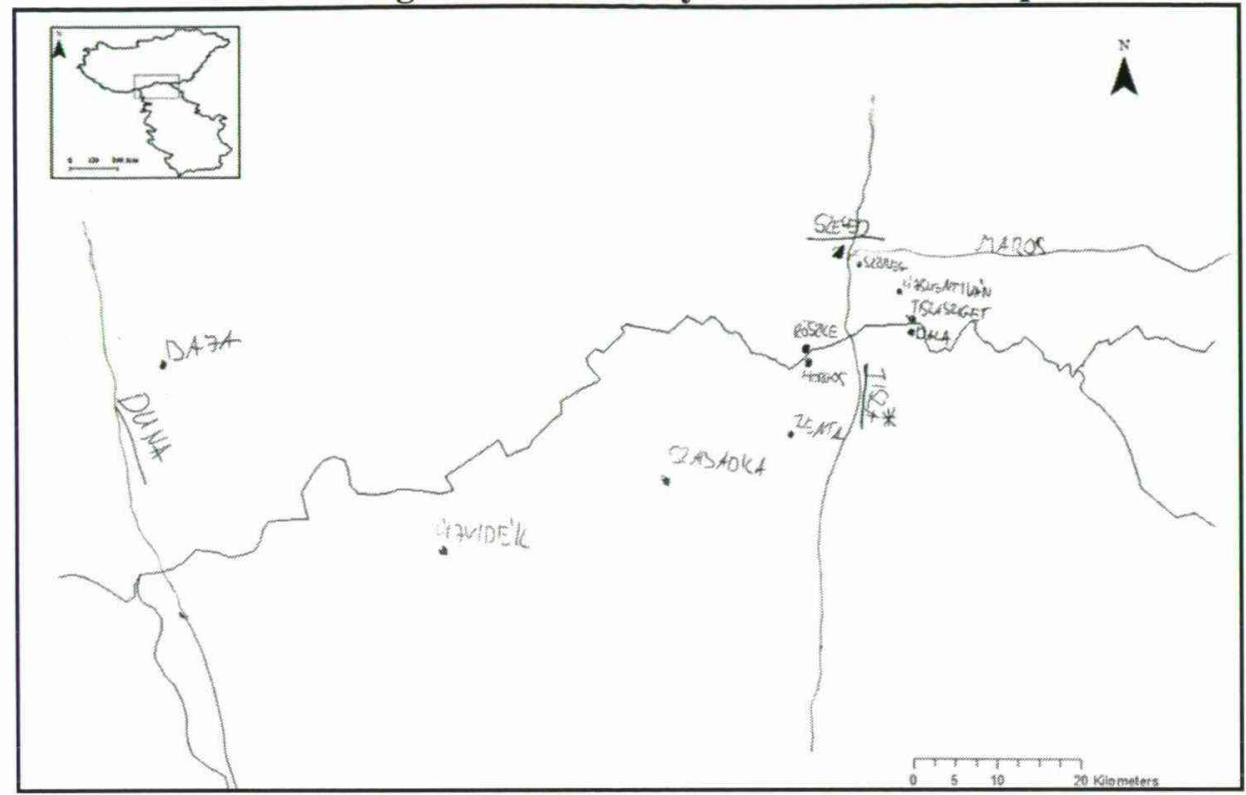

Forrás: A szerző felmérése alapján (2015)

4. ábra: Szétszoró-típusú mentális térkép

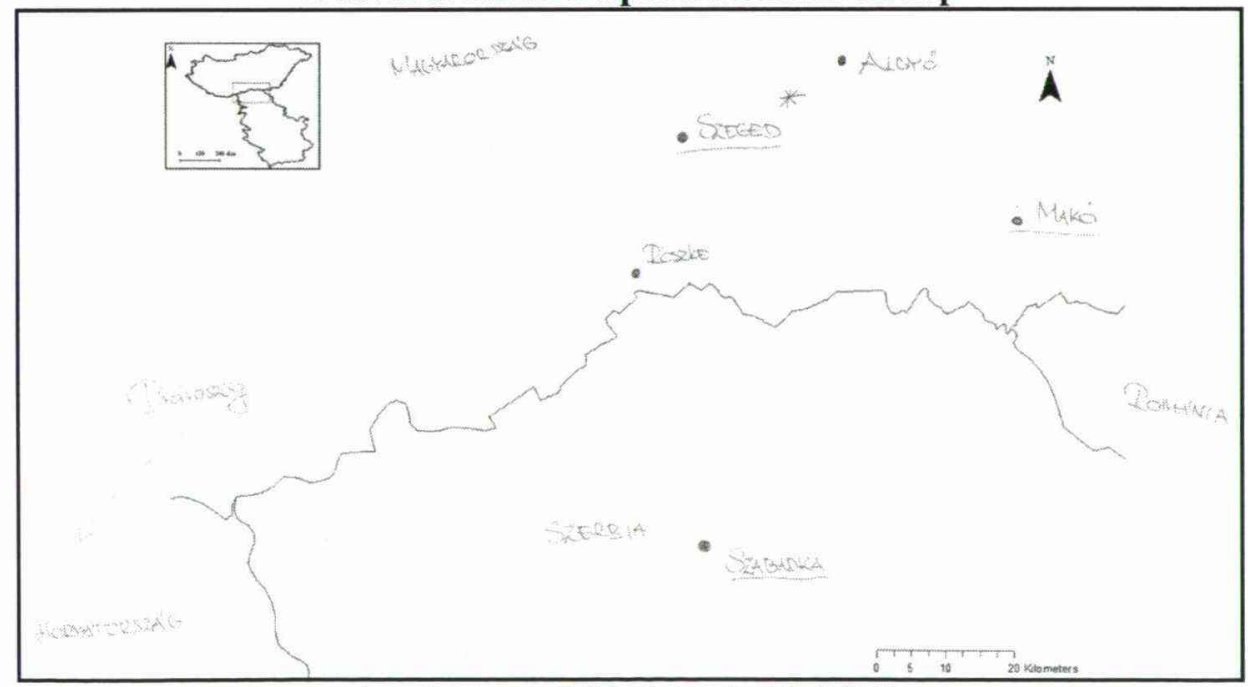

Forrás: A szerző felmérése alapján (2015)

Ha megvizsgáljuk, hogy az egyetmisták a tényleges földrjazi helyzethez képest hogyan jelölték településobjektumaikat, akkor a következőt tapasztalhatjuk, példaként említeve a 4. szétszoró-típusú ábra jelöléseit. Ahol is a települések egymáshoz viszonyított helyzete megfelelöen jelölt, de az eredeti helyzehez képest 
a magyar telelpülések északabbi, a szerb település, Szabadka esetében pedig déli eltolódást láthatunk (5. ábra).

5. ábra: Egy födrajztanár szakos hallgató mentális térképnek térbeli eltolódása

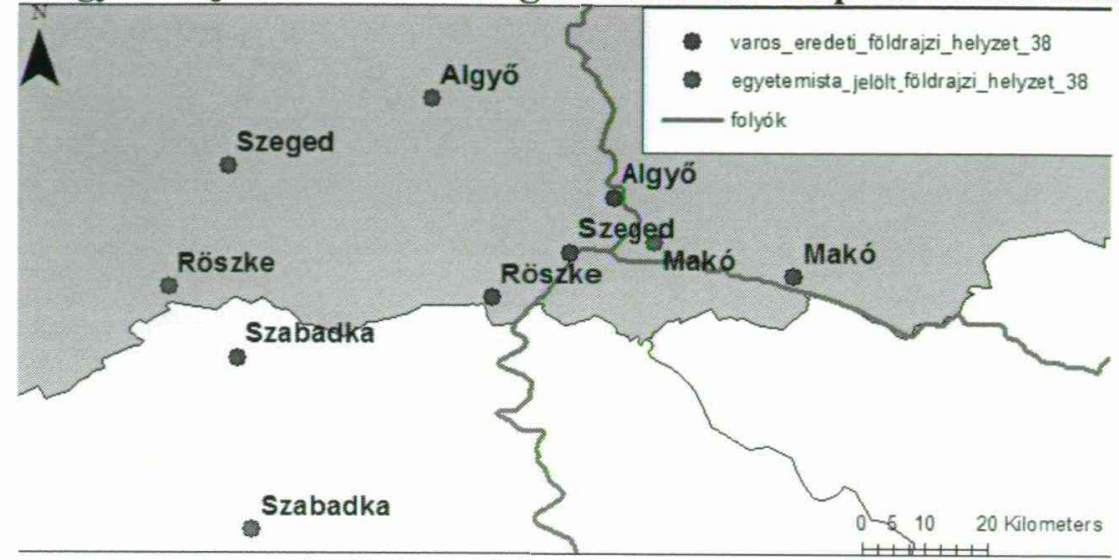

Forrás: A szerző felmérése alapján (2015)

Az ArcMap 10.3 szoftver környezeteben megvizsgáltuk azt is, hogy az ábrázolt települések milyen gyakorisággal jelennek meg a mentális téképeken. Így elmondhatjuk, hogy összességében a vizsgált terülten a legismertebb települések közé tartozik a magyarországi Szeged, Röszke, Ásotthalom és Baja, a határon túl pedig a szerbiai Szabadka és Zenta. Ugyanis tíznél többször került említésre Röszke, Szabadka és Szeged települések neve a térképeken.

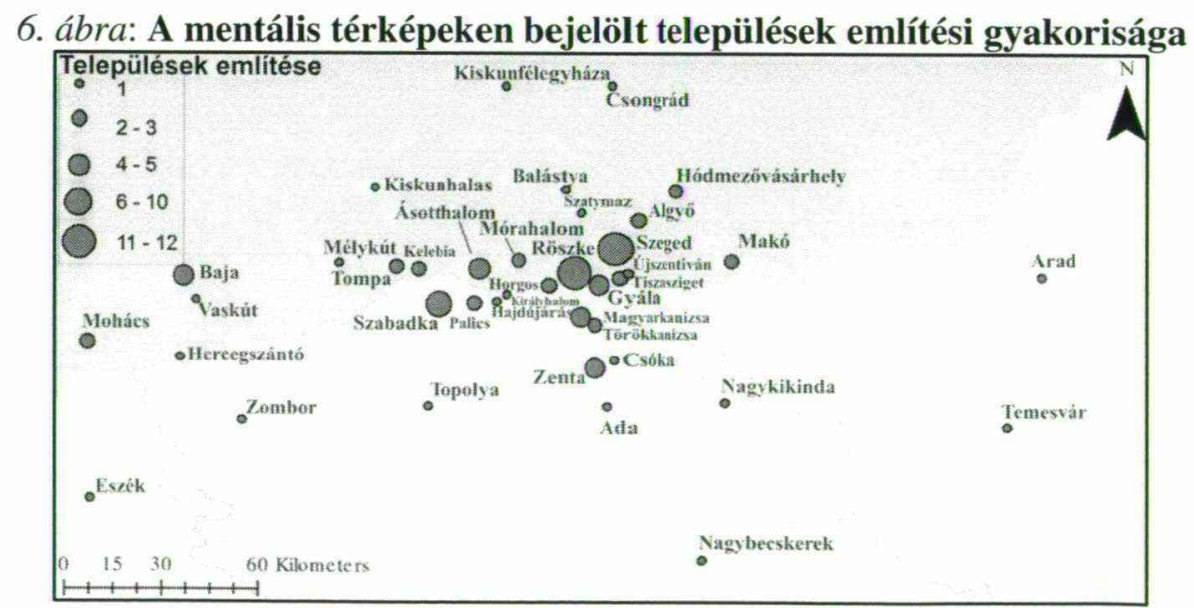

Forrás: A szerző felmérése alapján (2015)

Az 5. ábra tapasztalati alapján kíváncsiak voltunk arra, hogy a legtöbbször említett (6. ábra) települések, tehát Szeged, Röszke és Szabadka helyzetét hogyan, milyen égtáji, távolsági eltérésekkel jelölték a diákok térképeiken. Ezen térképek elkészítéséhez beszkenneltem az eredeti kérdőíves feladatlapokon lévő 
térképvázlatokat, majd az ArcMap 10.3 program segítségével kontrollpontok megadásával digitalizáltam be a diákok által megadott település helyeket. A magyarországi települések esetében rendelkezésemre álltnak a települések pontszerủ adatai mellett a település kiterjedését felölelő polygon típusú adatok is.

\section{7. ábra: Szeged földrajzi elhelyezkedése a diákok mentális térképein}

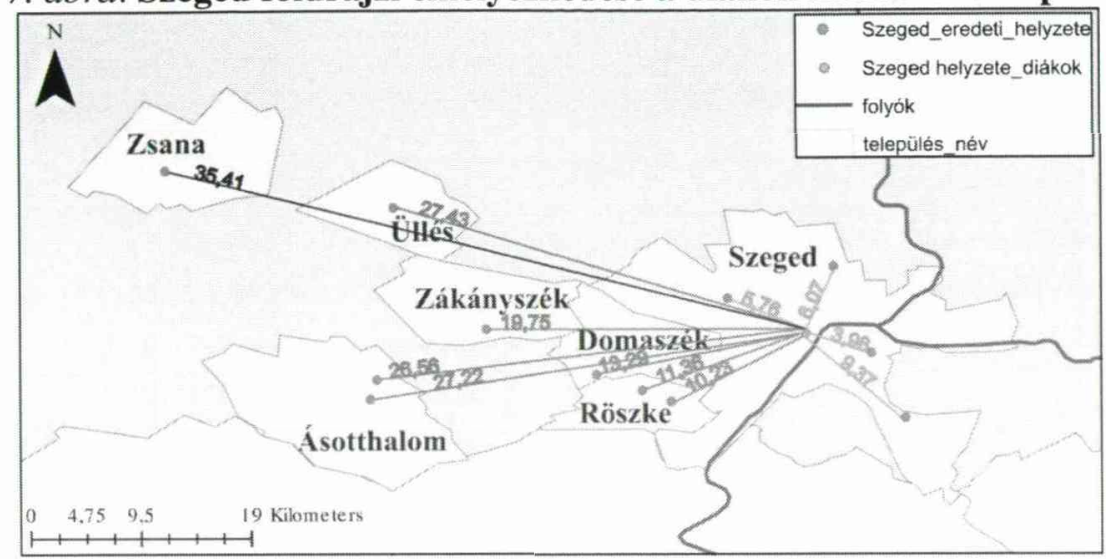

Forrás: A szerző felmérése alapján (2015)

A diákok 36,36\%-a jelölte Szeged települést annak tényleges településhatárai belülre, ezeket az eseteket jelöltük a térképen narancssárgával. A diákok 27,27\%-a Domaszék és Röszke, a 36,36\%-uk Üllés, Zákányszék és Ásotthalom területére helyezte el Szeged települését. A legtávolabbi jelölés 35,41 km-re, Zsana település helyére tette be a várost. Azon diákok közül, akik nem találták el a város tényleges helyzetét kivétel nélkül mind nyugatabbra helyezte el a települést, többségük az eredeti helyzettel egy vonalba (7. ábra).

Röszke település esetében a diákok közül csupán egy személy jelölte a települést annak tényleges kiterjedési környeztében. A többség ebben az esetben is inkább nyugatabbra helyzete el, a legnagyobb arányban Ásotthalom, majd Szeged területére kerültek a fejekben élő Röszke térkép-képzetek. A legtávolabbi elhelyezés itt is hasonlóképpen 35-36 km körül mozgott, mint Szeged esetében, ahol is Tompa területére került a település (8. ábra). 


\section{8. ábra: Röszke földrajzi elhelyezkedése a diákok mentális térképein}

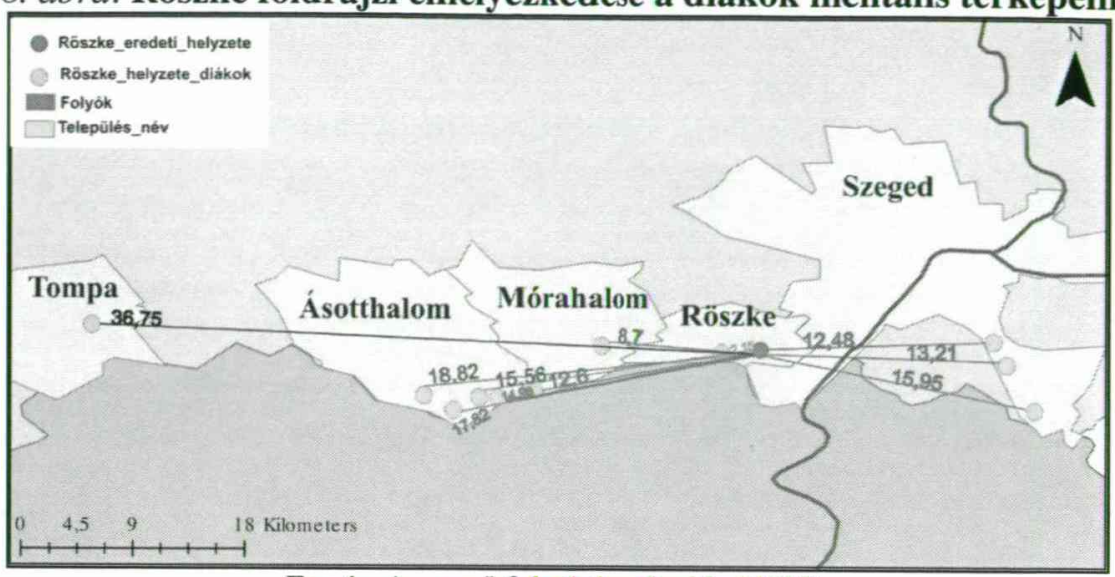

Forrás: A szerző felmérése alapján (2015)

Szabadka település esetében nem állt módomban polygon típusú adatbázis a bejelölések térbeli helyességének eldöntéséhez. Így a távolságok alapján vizsgáltam meg a bejelölt objektumokat. Elsősorban feltűnő az, hogy ebben az esetben is a diákok inkább nyugatabbra helyezték el jelöléseiket, illetve 25-50 kmes eltéréssel is jelölték a várost térképeiken (9.ábra).

\section{9. ábra: Szabadka földrajzi elhelyezkedése a diákok mentális térképein}

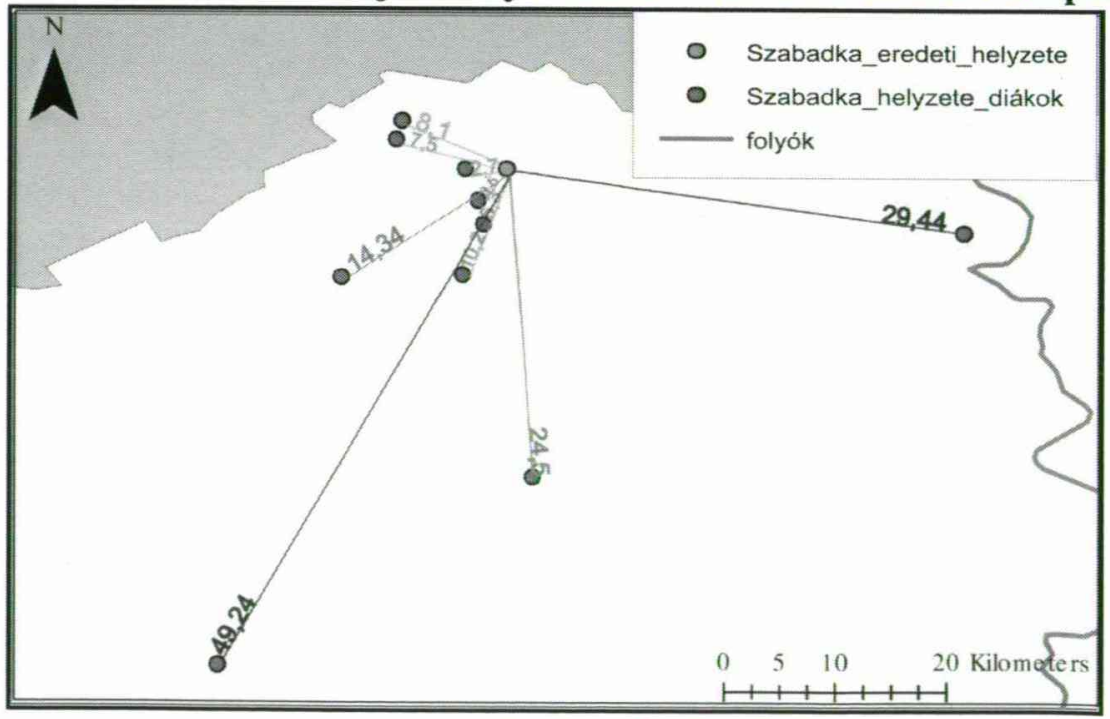

\section{4. Összegzés}

Forrás: A szerző felmérése alapján (2015)

Jelen módszertani vizsgálat célja volt egyrészt egy olyan mérőeszköz térképes feladatának értékelése, mely alkalmas arra, hogy felszínre hozzuk a mentális határképeket. A szegedi földrajztanár szakos hallgatók körében végzett kismintán 
történő felmérésnek köszönhetóen lehetővé vált a későbbi reprezentatív mintán történő módszertani kutatás metodikai feltárása. A négy részből álló kérdőív egy (1) térképes nyílt és két zárt végü (2) hovatartozás eldöntése, távolságészlelés; (3) attitüd-vizsgálat feladattípust, valamint a (4) háttérváltozók felvételére irányuló kérdéssort tartalmazott. $\mathrm{Az}$ első feladattípus (térképi bejelölés) kapcsán megállapítottam, hogy a kérdöíven alapuló mentális térképezéssel kapcsolatos irányított felidézés módszere alkalmas a fejekben élő képzetek feltárására, térképzetek kimutatására, valamint a feladat az instrukciókkal együtt megfelelően alkalmazható a határ menti kérdéskör vizsgálatára. Összességében megállapítható, hogy a kérdőív bizonyos módosítások után alkalmas a középiskolás diákok határképzeteinek feltérképezésre is.

A vizsgálat célja volt betekintést nyerni a földrajz szakos hallgatók Magyarország dél-keleti határvidékéről alkotott mentális képéről is. Az egyetemisták mentális térképeinek tartalmi vizsgálatakor azt tapasztaltam, hogy az államhatár merev szerepének oldódása nem jelenik meg az egyetemisták határképzeteiben. Állításomat a következőkkel indokolom: Annak ellenére, hogy a diákok közül szinte mindenki jelölt be nemcsak a magyarországi területen objektumokat az átlagos jelölésszám kilenc objektum körül alakult. Földrajzi tanulmányokat folytatók között ugyanakkor meglepö, hogy természetföldrajzi objektum átlagemlítése még az egyet sem éri el

A felmérés a magyar oldalon történő vizsgálatra korlátozódik, a jövőben egy átfogóbb kutatás részeként tervezem a román, szerb és szlovák állampolgárságú diákok magyar-román, magyar-szerb és magyar-szlovák határszakasszal kapcsolatos térérzékelés-felmérését is, kiterjesztve azt a háttérváltozókkal való összefüggés vizsgálatokra is. Ehhez kapcsolódóan a jövőben célom vizsgálni, hogy milyen tényezők játszanak szerepet a topográfiai tudás fejlődésére és a térérzékelés kialakulására: mennyiben befolyásolja az állandósult tudást az információs technológiai fejlödés (IKT-használat, GPS). Viszont ezen utóbbi kérdések megválaszolására és tanulmányozására majd a későbbiekben kerülhet sor.

\section{Irodalomjegyzék}

Bajmócy P., Csíkos Cs. (1997): Európai országok népszerüsége egyetemi hallgatók körében. Iskolakultúra, (6-7), 71-77.

Baranyi B. (2004): A határmentiség dimenziói: Magyarország és keleti államhatárai. Dialóg Campus Kiadó, Budapest-Pécs.

Cséfalvay Z. (1990): Térképek a fejünkben. Akadémiai Kiadó, Budapest.

Didelon, et al. (2011): A World of Interstices: A Fuzzy Logic Approach to the Analysis of Interpretative Maps. The Cartographic Journal, 48:(2), 100-107.

Downs, R., Stea, D. (1977): Maps in Minds: Reflections on Cognitive Mapping. New York: Harper and Row.

Downs, R. M., Stea, D. (2005): Térképek az elmében - gondolatok a kognitív térképezésről. In: Letenyei L. (szerk.): Településkutatás II. Ráció Kiadó, Budapest. 593-614.

Farsang A., Jori J. (1999): Adatok a 13-16 éves diákok mentális Európa-képéhez., A Földrajz Tanítása: Módszertani Folyóirat (Mozaik Kiadó, Szeged), 7:(4), 10-18.

Farsang A. (2011): Földrajztanítás korszerüen, Geolitera, Szeged. 
Garda V. (2009): Szubjektív térérzékeléssel kapcsolatos vizsgálatok elméleti háttere és alkalmazási területei. Tér és târsadalom, 23:(1), 43-53.

Hajdú Z. (2000): A határon átnyúló együttműködés potenciális lehetőségei Magyarország EUcsatlakozása után., In: Horváth Gy. (szerk.): A régiók szerepe a bövülö Európai Unióban. MTA Regionális Kutatások Központja, Pécs. 163-173.

Hardi T. (szerk.) (2015): Terek és tér-képzetek: Elképzelt és formalizált terek, régiók a Kárpátmedencében, Közép-Európában. 411 Somorja; Győr: Fórum Kisebbségkutató Intézet; MTA KRTK Regionális Kutatások Intézete, 9-10.

Hardi T. (1999): A határ és az ember. Az osztrák-magyar határ mentén élök képe a határról és a "másik oldalról"., In: Nárai M., Rechnitzer J. (szerk.): Elválaszt és összeköt: a határ. Társadalmi-gazdasági változások az osztrák-magyar határ menti térségben. MTA Regionális Kutatások Központja. 159-191.

Herendiné Kónya E. (2007): Kisiskolások térbeli tájékozódó képességének fejlesztési lehetôségei. Doktori (PhD) értekezés, Debreceni Egyetem, Debrecen.

Houtum, Henk van (1999): „Internationalisation and mental borders". Tijdschrift voor economische en sociale geografie, 90:(3), 329-335.

Kincses Á., Jakobi Á. (2012): A világ a diákok szemével. Területi Statisztika, 52:(3), 264-277.

Kiss J., Bajmócy P. (1996): Egyetemi hallgatók mentális térképei Magyarországon. A mental-mapek módszeréröl, MTA Regionális Kutatások Központja, Tér és társadalom. 10:(2-3), 55-68.

Kiss J. (2005): A mentális térkép., In: Nemes Nagy J. (szerk.): Regionális elemzési módszerek. ELTE Regionális Földrajzi Tanszék MTA ELTE Regionális Tudományi Kutatócsoport, Budapest. 96-98.

Koltai J., Ligeti A. S. (2015): A_határon túli területek szubjektív közelsége. In: Sik E., Surányi R. (szerk.) 2015: Határhatások. E-könyv, Hungarian edition. ELTE TáTK és Tárki Zrt., 316-331.

Lakotár K. (2004): Bennünk "élö" szomszédaink. Iskolakultúra, 14:(11), 109-116.

Lakotár K. (2009a): Gondolatainkban élö országképek. Tizenévesek kognitív országképei szomszédainkról. Pauz-Westermann, Celldömölk. 128

Lakotár K. (2009b): Tizenévesek kognitív országképei szomszédainkról az egyes régiókban. Területfejlesztés és Innováció, 3:(3), 27-34.

Lakotár K. (2011): A határainkon túli magyar tanulók kognitív Magyarország képe. NyugatMagyarországi Egyetem Savaria Egyetemi Központ Tudományos Közleményei, 18:(Természettudományok 13). 143-149.

Lakotár K. (2012): Magyarország mentális térképek a határainkon túlról. Területfejlesztés és Innováció, 6:(1), 10-18.

Lynch K. (1960): The image of the city. MIT Press, Cambridge.

Makádi M. (2012): A tanulók Európa-képzete: Egy térbeli intelligencia-felmérés tapasztalatai. $A$ Földrajz Tanítása Módszertani Folyóirat, 20:(4), 3-14.

Makádi M. (2013): A térlátás és a tapasztalatok kapcsolata: Egy térbeli intelligencia-felmérés tapasztalatai. A Földrajz Tanítása Módszertani Folyóirat, 21:(2), 3-14.

Milgram, S. (1972): A Psychological Map of New York City. American Scientist, 60:(1), 194-204.

Poreisz V. (2013): Az objektív és szubjektív térérzékelés vizsgálatának lehetséges módszerei. In: Karlovitz J. T. (szerk.): Ekonomické štúdie - teória a prax: Gazdasági tanulmányok, elmélet és gyakorlat. Komárno International Research Institute, Komárno. 369-376.

Rácz A. (2012): Szegregáció a fejekben. A statisztikai és a mentális társadalmi-és térbeli elkülönülés vizsgálata Szegeden. Doktori (PhD) értekezés. Budapesti Corvinus Egyetem, Budapest.

Saarinen T. F., Maccabe C. L. (1995): World patterns of geogephic literacy based on sketch map quality. The Professional Geographer, 47:(2), 196-204.

Sik D., Szécsi J. (2015): Iskolák a határokon, In: Sik E., Surányi R. (szerk.): Határhatások. Ekönyv, Hungarian edition (C ELTE TáTK és Tárki Zrt., 128-157.

Sik E., Surányi R. (szerk.) (2015): Határhatások. E-könyv, Hungarian edition. ELTE TáTK és Tárki Zrt., Budapest. 
Sudas, I., Gokten, C. (2012): Cognitive maps of Europe: geographical knowledge of Turkish geography students. European Journal of Geography, 3:(1), 41-56.

Székely A. (2002): A magyar-szlovák határmenti lakosság és önkormányzatok határképe 2002 nyarán, In: Szónokiné Ancsin G. (szerk.) Határok és az Európai Unió: Nemzetközi földrajzi konferencia. Szegedi Tudományegyetem Természettudományi Kar Gazdaság- és Társadalomföldrajz Tanszék, Szeged. 271-278.

Székely, A., Kotosz, B. (2005): A határmenti lakosság határképe az EU-csatlakozás elött. Statisztikai Szemle, 83:(12), 1111-1129.

Tolman, E. C. (1948): Cognitive maps in rats and men. Psychological Review, 55, 189-208.

Uszkai A. (2015a): Európai országkép kutatások a mentális térképezés módszerével, In: Karlovitz J. T. (szerk.): Fejlỏdó jogrendszer és gazdasági környezet a változó társadalomban. Kománo International Research Institute, Komárno. 95-101.

Uszkai A. (2015b): Fizikai és mentális határok a társadalmi térben, a mentális térképezés elméleti háttere és gyakorlati kutatásai, In: Hardi T. (szerk.): Terek és tér-képzetek. Fórum Kisebbségkutató Intézet, MTA KRTK Regionális Kutatások Intézete, Somorja-Győr.

Vida Gy. (2013): Az új országgyülési választókerületi beosztás és a társadalmi igazságosság kérdése, Csongrád megye példáján. In: Józsa K., Nagy Gy., Dudás R. (szerk.): Geográfus Doktoranduszok XIII. Országos Konferenciája. Szegedi Tudományegyetem Természettudományi Kar Gazdaság- és Társadalomföldrajz Tanszék, Szeged. 32. dokumentum 1-17.

Vida Gy. (2016): Az egyenlötlen politikai reprezentációt létrehozó választási földrajzi hatótényezök mérési lehetöségei. Területi Statisztika, 56:(6), 643-659.

Wiegand, P. (1998): Childrens Free Recall Sketch Maps of the World on a Spherical Surface. International Research in Geographical and environmental Education, 7:(1), 67-83. 